\title{
SAPROPHYTIC COMPETITION OF SOIL MICROFLORA AND Rhizoctonia Solani IN THE ROTATING AMENDED COMPOSTS PLANTED BY TOMATO
}

\author{
Asmar, A. YouseF ${ }^{*}$, Wazeer A. Hassan, Khadeeja A. SAido and Ibrahim E. Taher \\ Dept. Plant Protection, College of Agriculture, University of Duhok, Kurdistan Region-Iraq
}

(Received: April 24, 2018; Accepted for publication: May 14, 2018)

\begin{abstract}
The succession competitiveness of predominant saprophytic fungi, and bacteria colonized different amended composts, inoculated with propagules of Rhizoctonia solani were investigated after 20 and 40 days of the first and second rotation of tomato seedlings. Fungal communities of Alternaria alternata, Aspergillus flavus, A. niger, A. terreus, Fusarium sp., Penicillium spp., and a bacterium of Bacillus subtilis were isolated from substrates of pine leaf litter, mushroom's compost1, and control of (sandy loam soil). Microbial

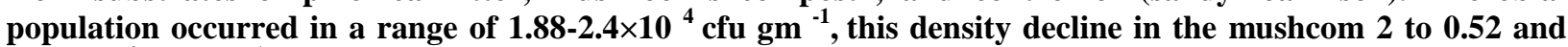

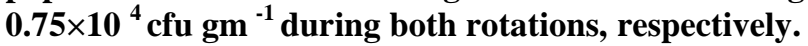

Amended composts with formulation of T. harzianum (T.h) and B. subtilis $10 \%$ at $10 \mathrm{gm} / \mathrm{kg}$ tomato seeds were instigated the saprobes competition during both rotations when insulated with 2.3 and $2.4 \times 10^{4} \mathrm{cfu} \mathrm{gm}^{-1}$. T. viride which was also heartening a comparable development particularly in the second rotation which observed with 1.87 and $2.15 \times 10^{4} \mathrm{cfu}^{-1}{ }^{-1}$.

The highest frequency for each of Penicillium spp.,with $16.3 \times 10^{4} \mathrm{cfu} \mathrm{gm}^{-1}$ and B. subtilis with $18.7 \times 10^{4}$ ${\mathrm{cfu} \mathrm{gm}^{-1} \text { were detected in the first rotation colonizing substrates of pine leaf litter and ( mushcom } 1 \text { ) }}^{-1}$ ) amended with $T$. h. \& B. sublilis. Therefore, these species are capable to develop and compete the pathogen in space and nourishment even under conditions of nutrient

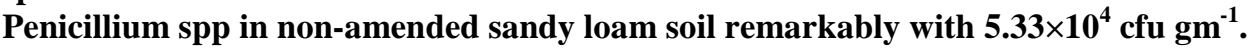
deficiency, hence, colonized of
\end{abstract}

KEYWORDS: R. solani, compost, T. harzianum, T. viride, B. subtilis and microbial activity

\section{INTRODUCTION}

$\boldsymbol{R}$ hizoctonia diseases occur throughout the world. They cause losses on almost all vegetables and flowers, several field crops, turf grasses, and perennial ornamentals, shrubs and trees. The most common symptoms on most plants are damping-off of seedlings and root rot, stem rot or stem canker of growing plants (Agrios, 2005).

Suppression of soil-borne pathogens as $R$. solani has been reported to be typically related to the level of total microbial activity present in the compost (Hoitinketal, 1997). Regardless of application biocontrol agent such as Trichoderma spp. and Bacillus subtilis or other antagonists, disease suppression by composts is mainly attributed to the opportunistic microbial population linked to the source of the organic matter in the compost, and this potential of suppressive compost can be restored by reintroducing a mixture of microorganisms, a specific organisms, or amendments (Dukare etal., 2011 and Noble, 2011). Furthermore, nutrients for antagonistic or beneficial organisms provided by organic matter or waste products released by other organisms (Haggag, 2002).

However, opportunistic fungi strains are the major components that grow in stacked masses of plant material, piles of agriculture such as mushrooms compost, forestry products and other accumulations of organic matter where the aerobic environment facilitates the basic conditions for their development and colonization during plant growth or after harvesting (Dhahir, 2013). These strains of Aspergillus, Penicillium, Cladosporium, Alternaria, Curvularia, Fusarium, bacterial genera of Bacillus, Pseudomonas, and more genera in the Ascomycetes and Deuteromycetes with a minimum at or above $20 \mathrm{C}^{\circ}$ and a maximum temperature range of up $62 \mathrm{C}^{\circ}$ for their growth and representative of soil microflora that can grow at above $45 \mathrm{C}^{\circ}$ (Ashraf etal., 2007; Mouchacca,1997).

The main reason how $B$. subtilis grew much faster than other microorganisms indigenous to the mature compost and antifungal or antibacterial 
substances, this obvious presumably through death of these competitive organisms at higher temperature .(Gunphae et al. 1990).

Indeed, thermophilic and mesophilic fungi have a powerful ability to degrade polysaccharide constituents of biomass like cellulose and consider the potential source of cellulolytic enzymes with scientific and commercial interest, these fungi can make the process more economical due to their thermostable enzymes, high rate of cellulolytic enzymes and ability to saccharify under non aseptic conditions (Maheshwari et al., 2000; Sohail et al., 2009).

Most of Trichoderma strains are mesophilic and cant protect germinating seeds from soilborne diseases caused by cold-tolerant strains of pathogens during cold spring (Samuels, 1996). On the other hand, $R$. solani surviving in the peat-mix could not be avoided though the competition of microbiota in the substrate (Dhahir, 2013). Chung and Hoitink (1990) revealed that R.solani propagules were not eradicated from tree bark compost when applied with their mesophiles isolates of Humicola spp. even application of $T$. harzianum, and this suggest the aim of addition such preservatives as sugar and other compounds to keep the spores of formulated isolates of Trichoderma and may increase their growth in the consumption (Panahian etal., 2012).

Finally, the concurrent utilization of the available carbon sources by thermophilic fungi might be an adaptive strategy for opportunistic growth in nature under conditions of low nutrient availability and thermal fluctuations in the environment. For more understanding of additional sustainable antagonism of the soil microbes, this work aimed to assess the succession competitive of most common saprophytic fungi with the inoculum potential of $R$. solani after two rotations of tomato seedlings planted in the pine leaf litter and mushrooms compost amended with each of commercial product of T. harzianum plus B. subtilis $10 \%$ and T. viridae.

\section{MATERIALS AND METHODS Composts origin:}

Substrates tested for sowing tomato seeds were:

1. A mixture of manufactured Mushroom's compost 1 (Mushcom. 1) and sandy loam soil $1: 4(\mathrm{v} / \mathrm{v})$, that include of wheat straw , chicken manure $30 \%$, urea ( trace), calcium carbonate $15 \%$ and Gypsum 3\%.
2. Mushroom's compost 2 (Mushcom.2) consisted of chopped wheat straw, wheat bran 5 $\%$ and Gypsum $5 \%$.

3. Chopped pine leaf litter.

4. Control treatment of sterilized sandy loam soil.

Source of antagonistic fungi, bacteria and tomato seeding:

Commercial product $($ Bio health $\mathrm{WSG}=$ Water Soluble Granular of T. harzianum and Bacillus subtilis $10 \%$ with Humic Acids $75 \%$ and Seaweed Extracts 5\% ) used at $10 \mathrm{gm} \mathrm{/} \mathrm{kg}$ seeds manufactured by Humintech $\mathrm{GmbH}$, Hecrdter Landstr., Dusseldorf, Germany. Another isolates of $T$. harzianum(Riafi) strain and $T$. viride were provided by Plant Protection Dept., College of Agric. \& Forestry, Univ. of Mosul, Iraq. The isolate of T. harzianum was grown in one liter conical flasks containing $250 \mathrm{gm}$ Mushroom's compost, $250 \mathrm{gm}$ wheat Barn $250 \mathrm{gm}$ and millet seeds and $250 \mathrm{ml}$ autoclaved Potato Dextrose medium, incubated for 25 days, and thoroughly mixing at 5 days interval to warrantee inoculum distribution. Contents of flasks were poured into plastic plates under aseptic conditions, left to air dry then mixed thoroughly before kept in sterilized polyethylene container at ambient temperature until using at $0.5 \%$, spore suspension was adjusted at $3 \times 10^{7} \mathrm{cfu} \mathrm{gm}^{-1}$ according to (Sallam et al., 2008).

Spore suspension of $T$. viride at $3 \times 10^{7} \mathrm{cfu} \mathrm{gm}^{-}$ ${ }^{1}$ prepared from cultures grown at $28{ }^{\circ} \mathrm{c}$ for 10 days. $20 \mathrm{ml}$ conidial suspension was drenched with each of substrate filled in pot of $15 \mathrm{~cm}$ in diameter. The composted substrates of $1 \mathrm{~kg}$ filled into pots and inoculated with $2 \%$ of pathogenic $R$. solani incubated at $28^{\circ} \mathrm{c}$ under darkness for seven days before planting. Control treatments included sandy -loam soil with inoculum of $R$. solani. Ten seeds of tomato were sown in each pot. Each treatment replicated four times, and irrigated as required. After 20 days, diseased tomato seedlings harvested and the container medium was reseeding and harvested again after another 20 days. Samples from control and amended substrates were collected for competitive opportunistic fungi and bacteria counts.

\section{Population of microbial community colonized different substrates}

After two week of harvesting diseased seedlings each of tomato rotation, soil samples of about $20 \mathrm{gm}$ were taken from different amended 
substrates within the root zones and placed in refrigerator $4^{0} \mathrm{C}$. Samples were quantified for opportunistic fungi and bacteria of B.subtilis using serial soil dilutions to $10^{-4}$ of sterile water. Nine plates divided into three replicates for each

medium were used. Total fungi and bacteria were computed as colony forming units (cfu) for each rotation.

Statistical Analysis: Systems software (SAS version 8, Institute, Inc.) were used for data analysis, subjected to analysis of variance mmmmmmmm ( ANOVA) and pooled together after testing of homogeneity of variance $(\mathrm{P} \leq 0.05)$. Means of the treatments were compared by Duncan Multiple Range Test at 0.05 levels.

\section{RESULTS AND DISCUSSION}

This work revealed that microbial biomass is the characteristic of micro organizations that participate in the biochemical cycle and constitute alive part of the soil organic matter. Accordingly, after 20 days for each of the first and second rotation of tomato seedlings, fungal communities of A. alternata, Aspergillus flavus, A. niger, A. terreus, Fusarium sp.,Penicillium spp., and a bacterium of B. subtilis were isolated. Population density of these soil microflora were colonized substrates of pine leaf litter and mushcom1 considerably with a range of 1.88 and $2.40 \times 10^{4}$

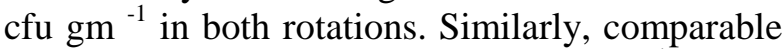
microbial community of 2.23 and $2.4 \times 10^{4} \mathrm{cfu}$ gm

${ }^{-1}$ was also developed in the control sandy loam soil revealed their ability to develop under poorly substrates environment. In contrast, compost mushcom 2 lead to significant reduction in the microbial occurrence since, their occurrences were restricted to 0.52 and $0.75 \times 10^{4} \mathrm{cfu} \mathrm{gm}^{-1}$ in both rotations, respectively (Fig.1), this may be due to mushcom 2 richness of cellulosic contents of wheat bran which fervor by most saprobes compared to other substrates, suppress pathogenic fungi of $R$. solani through competitive inhibition and the products of natural antibiotic, facilitative aerobe can survive extreme heat, and its ability to biodegrade hydrocarbons. ( Kinselia et al., 2010).

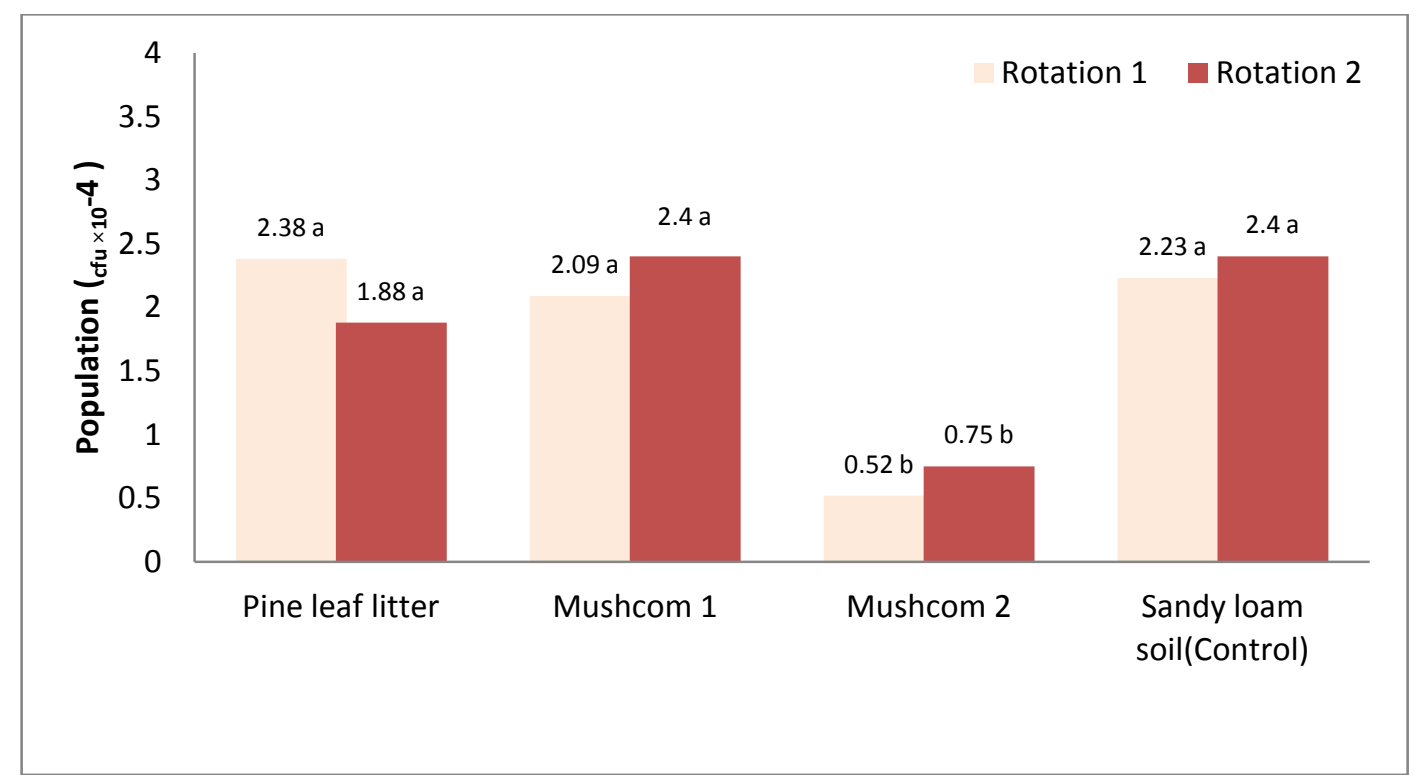

Fig.( 1): Effect of different substrates on the soil microbial population in both rotations.

Worthily, competition occurs between pathogenic and saprobes in the rhizosphere is a major concern for space and nutrients (Viterbo et al., 2007 ). Thus, competition can be divided into saprophytic for nutrients in the soil and infection sites on and in the roots (Fravel et al., 2003). Amendments of $T . h+B$. subtilis. Formulation were also encouraged the saprophytic colonization with 2.33 and $2.40 \times 10^{4} \mathrm{cfu} \mathrm{gm}^{-1}$ in both rotations, respectively (Fig.2). 


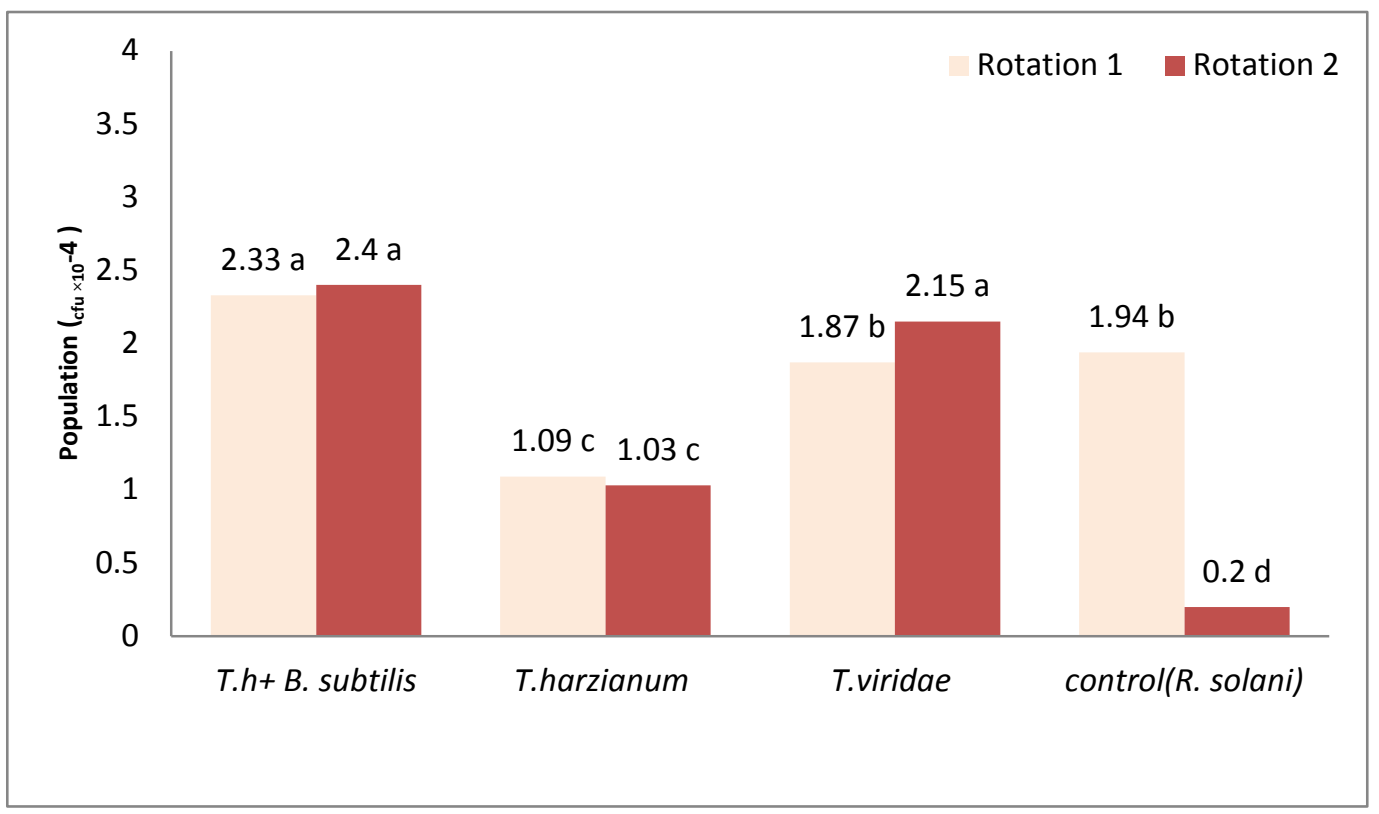

Fig.(2):- Effect of different amendments on the microbial population in both rotations.

These results confirmed the tolerance of $T$. harzianum to ammonia induced mycostasis leading to successful use of this species as abroad spectrum biocontrol agent (Papavizas , 1985). Furthermore, Trichoderma and Bacillus don't adversely affect the beneficial microorganisms in the rhizosphere and facilities the biocontrol of plant disease (Singh et al., 2008). T.viridae was also participated clearly in the creating a favorable condition for saprobes colonization with 1.87 and

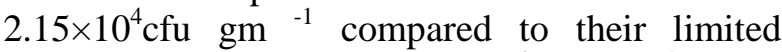
presence with 1.09 and $1.03 \times 10^{4} \mathrm{cfu} \mathrm{gm}^{-1}$ in the substrates amended with $T$. harzianum. Inoculum of R.solani (control) didn't prevent saprobes incidence particularly in the first rotation when

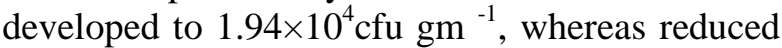
to $0.2 \times 10^{4} \mathrm{cfu} \mathrm{gm}^{-1}$ in the second one.

On the other hand, in spite of several soilborne pathogens have been reduced using composts made of different raw material agrees with what has been indicated by Borrero et al., (2004) and Litterick et al.,( 2004), their capacity to suppress $R$. solani that affects both seedlings and adult plants of many species, remains limited (Hassan et al., 2015; Hoitink and Boehm , 1999; Scheuerella et al., 2005 ).Assessment of saprobes population in the substrate samples were clarified in the (Fig. 3). High population of Penicillium $6.85 \times 10^{4} \mathrm{cfu} \mathrm{gm}^{-1}$ in the rotation 1 was restricted to $0.04 \mathrm{cfu}$ in the rotation 2, whereas B. subtilis was the predominant bacterium in the rotation 2 when colonized the examined substrates with $5.72 \times 10^{4} \mathrm{cfu} \mathrm{gm}^{-1}$, since it colonized the roots metabolizing nutrients of phosphates and nitrates into more bio available forms often used as biological soil amends and in composition facilities since $B$. subtilis survives the thermophilic phase.(Kinselia et al., 2010).

Several reports demonstrated that endophytic fungi of Aspergillus and Penicillium spp. might serve as the main components responsible for pronounced antifungal properties involved in protecting the host plant against attack of 


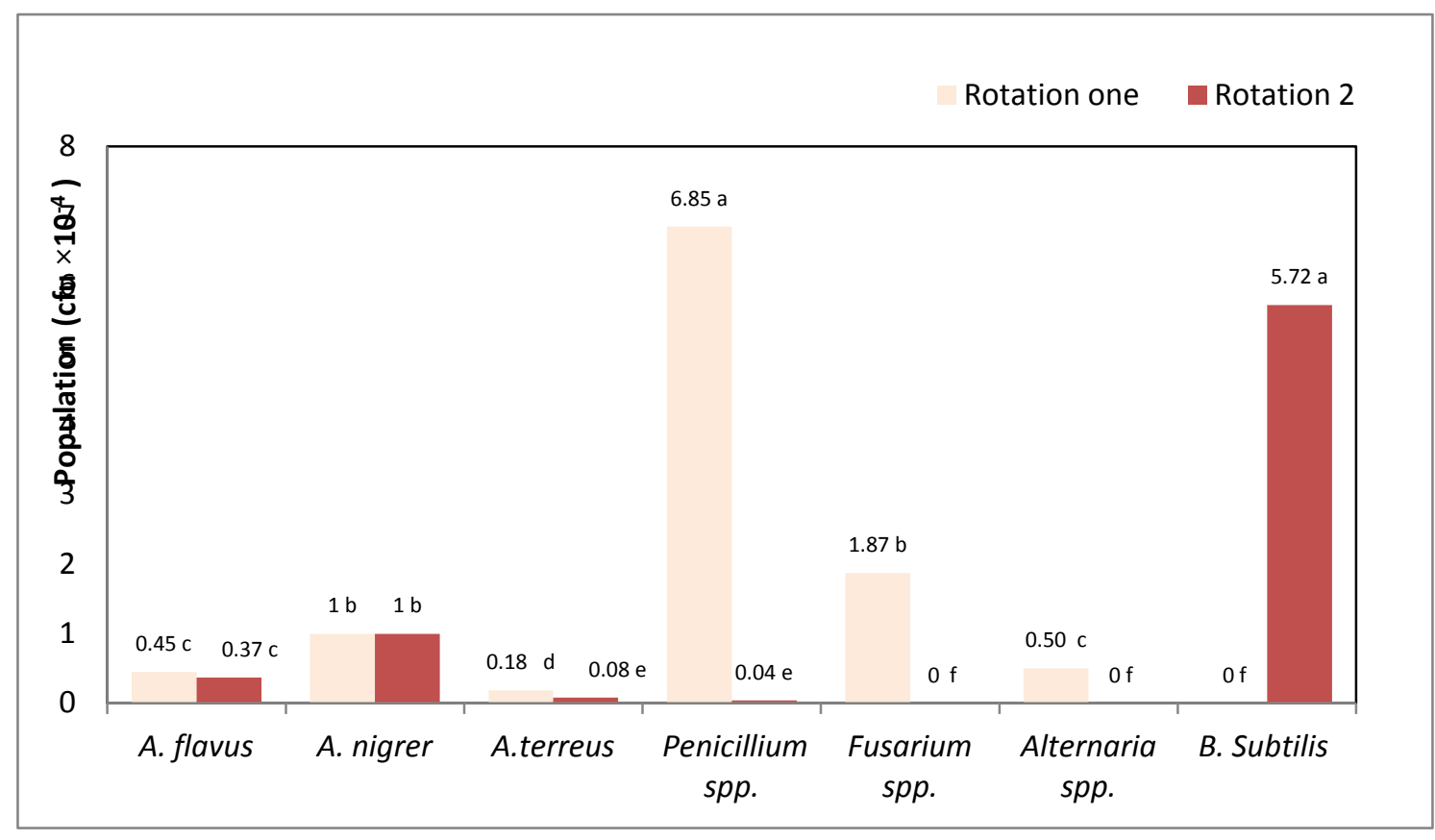

Fig.(3):- Microbial population $\left({ }_{\text {cfux } 10^{-4}}\right)$ in each gm isolated from compost samples in both rotation Virulent soil borne pathogens as R. solani (Wang et al., 2008; Xiao-Jun et al., 2012).

Literatures emphasized that control of such soil - borne pathogens as $R$. solani and Fusarium root rot was more effective in the soil amended with mushroom's compost, leaf litter, and manures with Trichoderma, these amendments stimulated ashift in the soil microbial population dynamics in the rhizosphere particularly fluorescent such as bacteria Bacillus spp. ( Stevens et al. , 2003), and each of Rhizopus stolonifer, Aspergillus spp. , Penicillium , Humicola spp., and others (Hassan and Yousif, 2013).Therefore, in addition to the most common biocontrol agents of Trichodema spp., several opportunistic fungi have been reported to be antagonist particularly in the organic composts against plant pathogens of $R$. solani, Pythium spp. and Phytophthora spp. successfully Aspergillus niger, Chaetomium spp.,
Penicillium spp. and Ulocladium atrum ( Kaewchai et al., 2009), as well as Bacterial genera of Bacillus, Pseudomonas and Streptomyces were also documented and widely applied in the biological control of $R$. solani (Sabaratnam;Traquair ,2002 and Yu et al., 2005). Results suggested that microbial community of Aspergillus and Penicillium have a greater biodiversity potential source of cellulase, and remarkable ability to saccharify under non- aseptic condition of substrates and of low nutrient availability and thermal fluctuations in the environment (Dhahir, 2013 and Maheshwari et al., 1987 ).The influence of amended substrates on the microbial dynamics associated with each of $R$. solani and Trichoderma spp. in the first rotation were represented in (Tabble1) 
Table (1): -Influence of substrates \& amendments on the microbial population in the first rotation.

\begin{tabular}{|c|c|c|c|c|c|c|c|c|}
\hline \multirow[b]{2}{*}{$\begin{array}{l}\text { क } \\
\text { C } \\
00 \\
\stackrel{0}{\mathbb{1}} \\
\mathbb{D} \\
\mathbb{D}\end{array}$} & \multirow[b]{2}{*}{ Amendments } & \multicolumn{7}{|c|}{ Population $\left(10^{4} \mathrm{cfu} \mathrm{gm}^{-1}\right)$} \\
\hline & & A. flavus & A. niger & A.terreus & $\begin{array}{l}\text { Penicillium } \\
\text { spp }\end{array}$ & $\begin{array}{l}\text { Fusariu } \\
m \text { sp. }\end{array}$ & $\begin{array}{l}\text { A.alt } \\
\text { erna } \\
\text { ta }\end{array}$ & R. solani \\
\hline \multirow{4}{*}{ 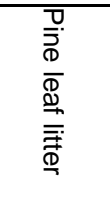 } & T.h + B. subtilis & $1.33 \mathrm{hij}^{*}$ & $0.667 \mathrm{ij}$ & $0.333 \mathrm{ij}$ & $16.33 \mathrm{a}$ & $0.0 \mathrm{j}$ & $0.0 \mathrm{j}$ & - \\
\hline & T.harzianum & $0.0 \mathrm{j}$ & $0.0 \mathrm{j}$ & $0.0 \mathrm{j}$ & $0.0 \mathrm{j}$ & $\begin{array}{l}7.33 \\
\text { cde }\end{array}$ & $0.0 \mathrm{j}$ & - \\
\hline & T.viride & $0.0 \mathrm{j}$ & $0.0 \mathrm{j}$ & $0.0 \mathrm{j}$ & $10.0 \mathrm{~b}$ & $3.66 \mathrm{fgh}$ & $0.0 \mathrm{j}$ & - \\
\hline & R. solani (Control) & $0.66 \mathrm{ij}$ & $0.0 \mathrm{j}$ & $0.66 \mathrm{ij}$ & $16.33 \mathrm{a}$ & $0.0 \mathrm{j}$ & $0.0 \mathrm{j}$ & + \\
\hline \multirow{4}{*}{ 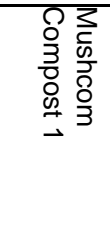 } & T.h + B. subtilis & 1.33hij & $0.0 \mathrm{j}$ & $0.33 \mathrm{ij}$ & $18.667 \mathrm{a}$ & $0.0 \mathrm{j}$ & $\begin{array}{l}1.33 \\
\text { hij }\end{array}$ & - \\
\hline & T.harzianum & $0.0 \mathrm{j}$ & $0.0 \mathrm{j}$ & $0.0 \mathrm{j}$ & $0.0 \mathrm{j}$ & $\begin{array}{l}8.33 \\
b c d\end{array}$ & $0.0 \mathrm{j}$ & - \\
\hline & T.viridae & $0.0 \mathrm{j}$ & $8.33 \mathrm{bcd}$ & $0.33 \mathrm{ij}$ & $3.00 \mathrm{ghi}$ & $0.0 \mathrm{j}$ & $0.0 \mathrm{j}$ & - \\
\hline & R. solani (Control) & $0.66 \mathrm{ij}$ & 1.33hij & $0.0 \mathrm{j}$ & $6.00 \mathrm{def}$ & $0.66 \mathrm{ij}$ & $0.0 \mathrm{j}$ & + \\
\hline \multirow{4}{*}{ 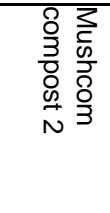 } & $\begin{array}{l}\text { T.harzianum+ } \\
\text { subtilis }\end{array}$ & $0.0 \mathrm{j}$ & $0.66 \mathrm{ij}$ & $0.0 \mathrm{j}$ & $0.66 \mathrm{ij}$ & $0.0 \mathrm{j}$ & $\begin{array}{l}6.66 \\
\text { cde }\end{array}$ & - \\
\hline & T.harzianum & $0.0 \mathrm{j}$ & $0.0 \mathrm{j}$ & $0.0 \mathrm{j}$ & $0.0 \mathrm{j}$ & $0.0 \mathrm{j}$ & $0.0 \mathrm{j}$ & - \\
\hline & T.viridae & $0.0 \mathrm{j}$ & $0.0 \mathrm{j}$ & $0.0 \mathrm{j}$ & $0.0 \mathrm{j}$ & $0.0 \mathrm{j}$ & $0.0 \mathrm{j}$ & - \\
\hline & R. solani (Control) & $0.66 \mathrm{ij}$ & $0.0 \mathrm{j}$ & $0.33 \mathrm{ij}$ & $3.66 \mathrm{fgh}$ & $0.0 \mathrm{j}$ & $0.0 \mathrm{j}$ & + \\
\hline \multirow{3}{*}{ 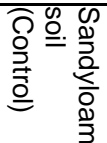 } & T.h+ B. subtilis & $1.00 \mathrm{hij}$ & $1.33 \mathrm{hij}$ & $0.0 \mathrm{j}$ & $5.33 \mathrm{efg}$ & $0.0 \mathrm{j}$ & $0.0 \mathrm{j}$ & - \\
\hline & T.harzianum & $0.0 \mathrm{j}$ & 1.00hij & $0.0 \mathrm{j}$ & $0.66 \mathrm{ij}$ & $9.00 \mathrm{bc}$ & $0.0 \mathrm{j}$ & - \\
\hline & T.viridae & 1.33hij & 1.00hij & $0.0 \mathrm{j}$ & $16.33 \mathrm{a}$ & $1.00 \mathrm{hij}$ & $0.0 \mathrm{j}$ & - \\
\hline
\end{tabular}

*Means followed by the same letters are not differ significantly $(\mathrm{P} \leq 0.05)$.

Substrates of control forest litter and (Mushrom 1) amended with $T . h+B$.

subtilis were colonized forcibly with Penicillium spp., ranging between 16 and $18.7 \mathrm{cfu}$ $\mathrm{gm}^{-1}$, these substrates were resemble to sandy loam soil ( control ) amended $18.7 \mathrm{cfu} \mathrm{mg}^{-1}$, these substrates were resemble to sandy loam soil ( control ) amended with T.v in the comparable existence of Penicillium . Moderate occurrence of Fusarium sp. was found in the T.v amendments of different examined substrates.

However, the crucial factor of the microbial competition includes concurrent utilization of the available carbon sources by soil microorganisms and this may be an adaptive strategy for opportunistic growth in nature. The aggressive competition of Penicillium spp. was apparent in the first rotation even under unfavorable conditions of non- amended sandy loam soil i. e lack of nutrients. Deuteromycetes such as Penicillium species are very common soil borne saprophyte fungi and are known to be potent antagonists of such pathogens as Fusarium (Sabuquillo et al., 2005).The competiveness of microbial dynamics were apparent in their great wide spread colonization during rotation 1 , since the pathogenic $R$. solani was isolated in just nonamended substrates of sandy - loam soil.

In the second rotation (Table 2) B. subtilis was mostly recovered substrates in spite of amendments when re isolated by $45 \%$ in the sandy loam soil amended with T.h+B. subtilis, considerable density of this bacterium 13.66 and $14 \times 10^{4} \mathrm{cfu} \mathrm{gm}^{-1}$ was found in the forest litter and (Mushcom 1) amended with T.v, the presence of other opportunists of Aspergillus spp. were rarely or not found.

Amendments with organic matter of compost improve plant health; the mechanism of diseases suppression coincide with many variable within examined substrate that need to be simultaneously monitored. During second rotation when the most nutrients depleted, $R$. solani was forcibly recolonized non- amended substrates of sandy loam soil and other treatments which lost their contents of microbial competition of most opportunistic fungi in spite the occurrence of $B$. 
Table( 2):- Influence of substrates \& amendments on the microbial population in second rotation.

\begin{tabular}{|c|c|c|c|c|c|c|c|}
\hline \multirow[b]{2}{*}{ 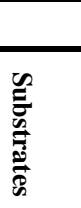 } & \multirow[b]{2}{*}{ Amendments } & \multicolumn{6}{|c|}{ Population $\times 10^{4}{\mathrm{cfu} \mathrm{gm}^{-1}}^{-1}$} \\
\hline & & A. flavus & A. niger & A.terreus & $\begin{array}{l}\text { Penicillium } \\
\text { spp }\end{array}$ & B.subtilis & R.solani \\
\hline \multirow{4}{*}{ 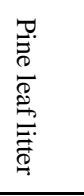 } & $\begin{array}{c}\text { T.harzianum }+B . \\
\text { subtilis }\end{array}$ & $0.33 \mathrm{~d} *$ & $0.00 \mathrm{~d}$ & $1.00 \mathrm{c}$ & $0.00 \mathrm{~d}$ & $1.00 \mathrm{c}$ & - \\
\hline & T.harzianum & $0.00 \mathrm{~d}$ & $0.00 \mathrm{~d}$ & $0.33 \mathrm{~d}$ & $0.00 \mathrm{~d}$ & $0.00 \mathrm{~d}$ & + \\
\hline & T.viridae & $0.33 \mathrm{~d}$ & $14.66 \mathrm{~b}$ & $0.00 \mathrm{~d}$ & $0.00 \mathrm{~d}$ & $14.00 \mathrm{~b}$ & - \\
\hline & R. solani (Control) & $1.00 \mathrm{c}$ & $0.00 \mathrm{~d}$ & $0.00 \mathrm{~d}$ & $0.33 \mathrm{~d}$ & $4.66 \mathrm{c}$ & ++ \\
\hline \multirow{4}{*}{ 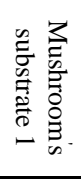 } & $\begin{array}{c}\text { T.harzianum }+ \\
\text { Bacillus } \\
\end{array}$ & $0.00 \mathrm{~d}$ & $0.33 \mathrm{~d}$ & $0.00 \mathrm{~d}$ & $0.00 \mathrm{~d}$ & $0.00 \mathrm{~d}$ & + \\
\hline & T.harzianum & $0.33 \mathrm{~d}$ & $0.00 \mathrm{~d}$ & $0.00 \mathrm{~d}$ & $0.00 \mathrm{~d}$ & $0.00 \mathrm{~d}$ & + \\
\hline & T.viridae & $0.00 \mathrm{~d}$ & $0.00 \mathrm{~d}$ & $0.00 \mathrm{~d}$ & $0.00 \mathrm{~d}$ & $13.66 \mathrm{~b}$ & - \\
\hline & R. solani (Control) & $0.66 \mathrm{~d}$ & $0.00 \mathrm{~d}$ & $0.00 \mathrm{~d}$ & $0.00 \mathrm{~d}$ & $0.00 \mathrm{~d}$ & ++ \\
\hline \multirow{4}{*}{ 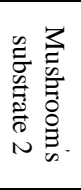 } & $\begin{array}{c}\text { T.harzianum }+B . \\
\text { subtilis }\end{array}$ & $0.33 \mathrm{~d}$ & $0.00 \mathrm{~d}$ & $0.00 \mathrm{~d}$ & $0.00 \mathrm{~d}$ & $0.00 \mathrm{~d}$ & - \\
\hline & T.harzianum & $0.66 \mathrm{~cd}$ & $0.33 \mathrm{~d}$ & $0.00 \mathrm{~d}$ & $0.33 \mathrm{~d}$ & $0.00 \mathrm{~d}$ & - \\
\hline & T.viridae & $0.00 \mathrm{~d}$ & $0.00 \mathrm{~d}$ & $0.00 \mathrm{~d}$ & $0.00 \mathrm{~d}$ & $0.00 \mathrm{~d}$ & + \\
\hline & R. solani (Control) & $1.00 \mathrm{c}$ & $0.00 \mathrm{~d}$ & $0.00 \mathrm{~d}$ & $0.00 \mathrm{~d}$ & $12.33 \mathrm{~b}$ & ++ \\
\hline \multirow{4}{*}{ 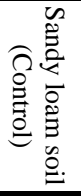 } & $\begin{array}{l}\text { T.harzianum }++B . \\
\text { subtilis }\end{array}$ & $0.00 \mathrm{~d}$ & $0.00 \mathrm{~d}$ & $0.00 \mathrm{~d}$ & $0.00 \mathrm{~d}$ & $45.00 \mathrm{a}$ & - \\
\hline & T.harzianum & $0.66 \mathrm{~cd}$ & $0.33 \mathrm{~d}$ & $0.00 \mathrm{~d}$ & $0.00 \mathrm{~d}$ & $1.00 \mathrm{c}$ & - \\
\hline & T.viridae & $0.00 \mathrm{c}$ & $0.33 \mathrm{~d}$ & $0.00 \mathrm{~d}$ & $0.00 \mathrm{~d}$ & $0.00 \mathrm{~d}$ & + \\
\hline & R. solani (Control) & $0.66 \mathrm{~cd}$ & $0.00 \mathrm{~d}$ & $0.00 \mathrm{~d}$ & $0.00 \mathrm{~d}$ & $0.00 \mathrm{~d}$ & ++ \\
\hline
\end{tabular}

*Means followed by the same letters are not differ significantly $(\mathrm{P} \leq 0.05)$.

- no colonized, + slight colonization, ++ density colonization

\section{CONCLUSION}

We conclude that microbial community colonized amended substrates particularly of mushroom's compost 1 with commercial product of T.h\&B. subtilis was richness in the nutrient necessary to sustenance and development of saprophytes competition against propagules of $R$. solani in their dynamics space and nutrients. This was clarified when computing damping off of tomato seedlings which reduced remarkably during the first rotation (Hassan et al., 2015).

The decline of the microbial colonization in the second rotation may be attributed to the relative depletion of nutrients available in the container composted media necessary for microbial dynamics. The future challenge is the identification for specific parameters for predicting the suppressiveness of each organic amendment in combination with each pathogen species.

\section{REFERENCES}

-Ashraf, R.; Shahid, F. and Ali, T.A.(2007). Association of fungi, bacteria and actinomycetes with different compost. Pakistan J. of Botany 39 : 2141-2151.

-Borrero, C.; Trillas, M.I.; Ordovs, J.; Tello, J. and Aviles, M.(2004). Biocontrol mechanisms of Trichoderma strains. International Microbiology7 (4):249-260.

-Chung, Y.R.and Hoitink, A.J. (1990). Interactions between thermophilic fungi and Trichoderma hamatuim suppression of Rhizoctonia damping -off in a bark compost- amended container medium. Phytopathology 80:73-77.

-Dhahir, H. M. (2013). Effect of compost media, fertilization and Trichoderma harzianum on Rhizoctonial damping - off. M. Sc. Thesis, Faculty of Agriculture and Forestry, University of Duhok. 86pp.

-Dukare, A. S.; Prasanna, R.; Dubey, S.C.; Naim,L.;Chaudhary,V.; Singh, R. and Saxena, A. K.(2011).Evaluation novel microbes amended compost as biocontrol 
agents in tomato. Crop protection 30: 436442.

-Fravel, D.; Olivain,C. and Alabouvette, C. (2003). Fusarium oxysporum and its biocontrol.New Phytol.157:271-279.

-Gunphae, c.; Sasaki, M. ; Shoda, M.; and Kubota, H. 1990. Characteristics of B. subtilis isolated from compost suppressing phytopathogenic microorganisms. Soil Science and plant nutrition 36(4):575-586S

-Haggag, W.M. (2002). Sustainable agriculture management of plant diseases. Journal of Biological Sciences 2: 280-284.

-Hassan, W. A. and Yousif, A.A. (2013). Soil recolonization by saprophytic fungi after solarization and soil amendments. Proceeding of the $1^{\text {st }}$ International Scientific Conference. University of Zakho, April , P. 23-25.

-Hassan, W. A.; Taher, I. E.; Saido, K. A. and Ali, A. S. (2015). Antagonism succession of Trichoderma against Rhizoctonia dampingoff on tomato in composted container media. Bull. Iraqi Nat. Hist. Mus. 13(4):41-44 .

-Hoitink, A.J. (1990). Production of disease suppressive compost and container media, and microorganisms culture for use there in. U.S. Patent No. 4,960,348

-Hoitink, H. A. J.; Stone, A. G. and Han, D. Y.(1997). Suppression of plant diseases by composts. Hort. Science. 32:184-187.

-Hoitink, H.A. J. and Boehm, M.J. (1999). Biocontrol within the context of soil microbial communities: a substratedependent phenomenon. Annual Review of Phytopathology 37: 427-446.

-Kaewchai, S.; Soylong, K. and Hyde, K. D.(2009). Myco-fungicides and fungal biofertilizers. Fungal Divers 38:25-60.

-Kinselia K; Schulthes, C. P; Morris, T. F. and Stuart, J. D. (2010).Rapid quantification of B. subtilis antibiotics in the rhizosphere. Soil Biology and Biochemestry 42(7). 1009-1192.

-Litterick, A. M.; Harrier, L.; Wallace, P.; Waston, C. A. and Wood, M. (2004). The role of un composted materials, composts, manures, and composts extracts in reducing pest and disease incidence and severity in sustainable temperature agriculture and horticulture crop production - a review.
Critical Reviews in plant sciences 23: 453479.

-Maheshwari, R. ;Kamalam P. T. and B. Alasubramanyam P. V. (1987). The biogeography of thermophilic fungi. Current Science 56 : 151- 155.

-Maheshwari, R.; Bhardwaj, G. and Bhat, M. K. (2000).Thermophilic fungi: Their Physiology and enzymes. Micrbiol. Mol. Biol. Rev. 63, 461-488.

-Mouchacca, J. (1997). Thermophilic fungi: biodiversity and taxonomic status. Cryptogrammic Mycol 18:19-69.

-Noble, R. (2011). Risks and benefits of soil amendment with composts in relation to plant pathogens. Australasian Plant Pathology. 40:157-167.

-Panahian, GR, Rahnama, K. and Jafari, M. (2012). Mass production of Trichoderma spp., and application. Int. Res. J. Appl. Basic Sci. 3 (2): 292-298.

-Papavizas, G. C. (1985). Trichodermaand Gliocladium: biology , ecology, and potential for biocontrol . Annual Review Phytopathology. 23 : 25- 54.

-Sabaratnam, S. and Traquair, J. A. (2002). Formulation of Streptomyces biocontrol agent for the suppression of Rhizoctonia damping off in tomato transplants. Biological control 23: 245-253.

-Sabuquillo, P., De Cal, A., Melgarejo, P.( 2005). Dispersal improvement of a powder formulation of Penicillium oxalicum, a biocontrol agent of tomato wilt. Plant Disease. 89: 1317-1323.

-Sallam, N. M. A. , Abo- Elyousr, K. A. M. and Hassan, M. A. E. (2008). Evaluation of Trichoderma species as biocontrol agent for damping - off and wilt diseases of Phaseolus vulgaris $L$. and efficacy of suggested formula . Egypt J. Phytopathol. 36 ( 1-2) : 81-93.

-Samuels, G. J. ( 1996). Trichoderma: a review of biology and systematic of the genus. Mycology Research 100: 923-953.

-Scheuella, S. J.; Sullivan, D. M. and Mahaffee, W.F.(2005). Suppression of seedling damping-off caused by Pythium ultimum, $P$. irregular, and Rhizoctonia solani in container media amended with a diverse range of Pacific Northwest compost sources. Phytopathology 95: 306-315. 
-Singh, V.; Joshi, B. B.; Awasthi, S. K.; Srivastava, S. N. (2008). Ecofriendly management of red rot disease of sugarcane with Trichoderma strains . Sugar Tech. 10(2) : 158- 161 .

-Sohail, M.; Naseeb, S.;Sherwani, S. K.; Sultana, S.; Aftab, S.; Shahzad, S.; Ahmed, A. and Khan, S.A.(2009). Distribution of hydrolytic enzymes among native fungi: Aspergillus the pre-dominate genus of hydrolase producer. Pakistan Journal of Botany 41(5):2567-2582.

-Stevens C. ; Khan V. A. ; Rodriguez- Kabana R. ; Ploper L. D. ; Backman P. A. ; Collins D. J. ; Brown J. E. ; Wilson M.A. and Igwegbe E. C. K. (2003). Integration of soil solarization with chemical, biological and cultural control for the management of soil borne disease of vegetables. Plant and soil 253 : 493- 506.

-Viterbo, A.; Inbar, J.; Hadar, Y. and Chet,I. (2007). Plant disease biocontrol and induced resistance via fungal mycoparasites. In:Kubicek CP, Druzhhinina IS(eds) Environmental and microbial relationships, the mycota, $2^{\text {nd }}$ edn. Vol.5 Springer-Verlag, Berlin, pp127-146.

-Wang, F.Z.; Fang, Y.C.; Zhu, T.J.; Zhang, M. ; Lin, A.Q.; Gu, Q.Q. and Zhu, W. M. ( 2008). Seven new prenylated indole diketopiperazine alkaloids from holothurians derived fungus Aspergillus fumigates .Tetrahedorm. 64: 7986-7991.

-Xiao- Jun Li ;QiangZh.; An- Ling Zh. and JinMing G.( 2012). Metabolites from Aspergillus fumigates, an Endophytic Fungus Associated with Melia azedarach, and Their Antifungal, Anti feed ant, and Toxic Activities. Journal of Agricultural and Food Chemistry.60: 3424- 3431.

-Yu, J.; Cleveland, T.; Nierman, W. and Bennett, J. (2005). Aspergillus flavus genomics: gateway to human and animal health, food safety, and crop resistance to diseases. Rev.Iberoam. Micol. 22: 194-202.

هوقركييا جه ند كييانهوهيَّن ئاخي ين هور دكه ل ئيّشكهر Rhizoctonia solani د خولين جا ندنا

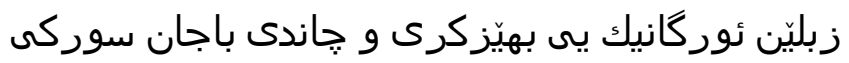

ئهق قهكولينه هاته ئهزامدان ل سهر ههثركى يا ل دويف ئيّك يا كهروويا وبهكتريا ئهويّن بهربهلاث

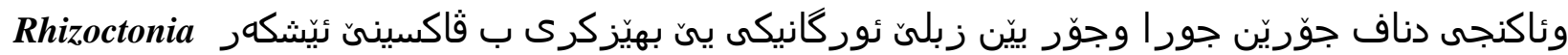
solani

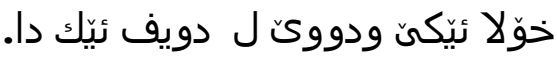
Bacillus subtilis, Fusarium sp., Penicillium spp., Alternaria alternarnata, Apergillus flavus, A. هاتنه ثهدركرن ز زبلى بهرماييّن بهلكيّن كازا ودوو زبليّن زيّدهكرنا مهشرومى زئاخا

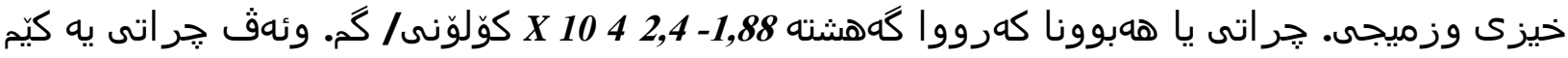

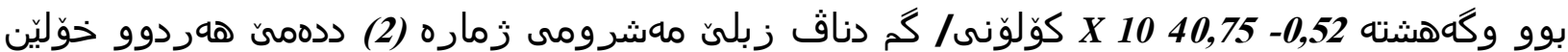

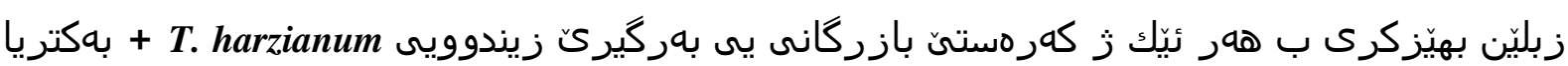
B. subtilis10\%

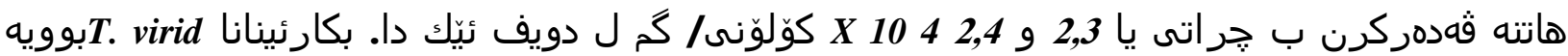

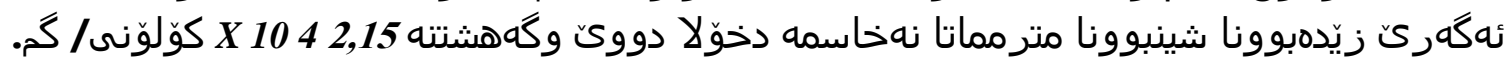




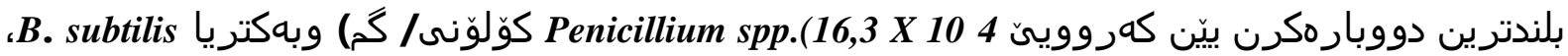

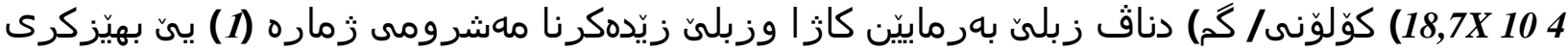

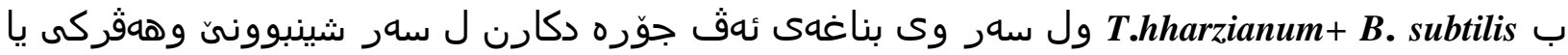

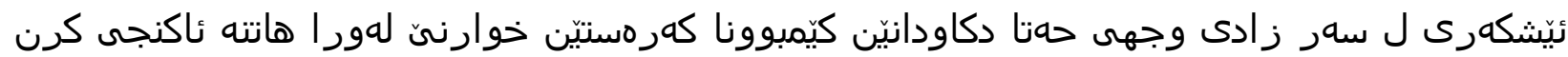

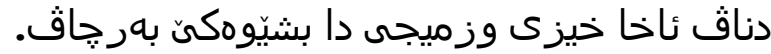

التنافس الرمي لبعض احياء التربة الدقيقة مع الفطر الممرض Rhizoctonia solani في الدورات الزراعية للاسمدة العضوية المدعمة و المزوعة بالطماطة

الخلاصة

تم البحث عن المنافسة المتعاقبة للفطريات و البكتريا الرمية السائدة والمستوطنة لانواع مختلفة من الاسمدة العضوية المدعمة والمعداة بلقاح الممرض Rhizoctonia solaniبعزلها بعد دورتين زراعيتين لبادرات الطماطة بواقع 20 و 40 يوم اللدورة الاولى و الثانية على التوالي.

Alternaria alternata , Aspergillus flavus, A. niger,A. terreus, Fusarium sp., عزلت الفطريات Bacillus subtilis من سماد مخلفات اوراق الصنوبر , و نوعين من سماد اكثار المشروم, و

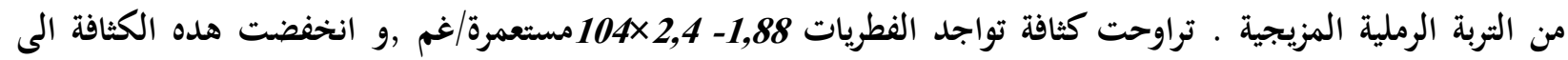
104×0,75-0,52 مستعمرة/غم في سماد المشروم رقم (2) خلال دورتي الزراعة.

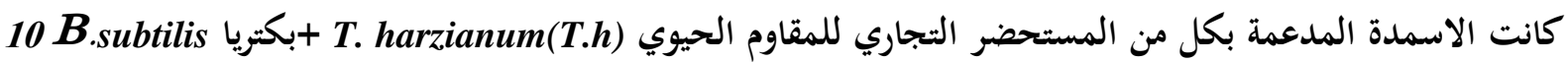
\% بمعدل 10 غم/كغم بذور طماطة مشجعة للمنافسة الرمية في كلا الدورتين فقد عزلت بكثافة 2,3 و 2,4 × 104 مستعمرة

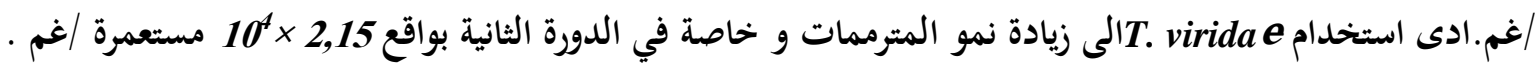
ظهرت اعلى كثافة للفطر . 10 10 16.3)Penicillium spp مستعمرة /غم) و بكتريا 10 18,7)B.subtilis مستعمرة

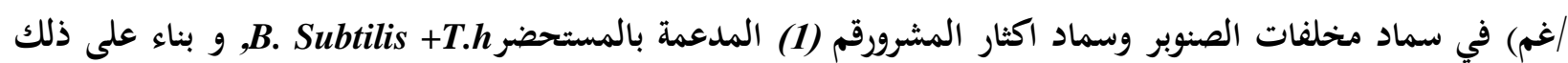
فان هذه الانواع قادرة على النمو و منافسة الممرض في الغداء و المكان حتى في ظروف نقص المغذيات و لهذا فقد استوطنت التربة المزيجية الرملية بشكل لافت. 